\title{
Analysis of the Correlation between Expressions of HSP90 $\alpha$, HSP90 $\beta$, and GRP94, and the Clinicopathologic Characteristics in Tissues of Non-Small Cell Lung Cancer Patients
}

\author{
Mi Kyeong Kim \\ Department of Clinical Laboratory Science, Gimhae College, Gimhae, Korea
}

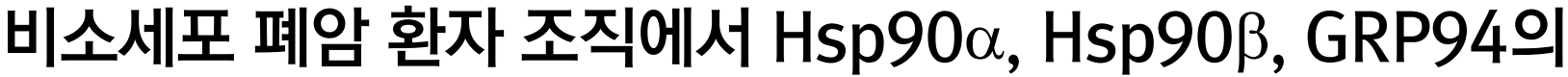 발현과 임상병리학적 특성과의 상관관계 분석}

김미경

김해대학교 임상병리과

\begin{abstract}
Heat shock proteins (HSPs) are induced as a self-defense mechanism of cells when exposed to various external stresses, such as high fever, infection, free radicals, and heavy metals. They affect the prognosis in the process of tumor formation. HSP is classified into four families: HSP27, HSP60, HSP90, and HSP100, depending on molecular weight. Heat shock protein 90 (HSP90), a molecular chaperone, plays an important role in the cellular protection against various stressful stimuli and in the regulation of cell cycle progression and apoptosis. In the present study, we assessed the differential expression of HSP90 family proteins in non-small cell lung cancer (NSCLC), and the correlation of their expression levels with clinicopathologic factors and patient survival rates. The result of this study can be summarized as follows; HSP90 $\alpha$ showed higher expression in patients with no lymphovascular invasion ( $p=0.014$ ). HSP90 $\beta$ showed a higher expression of squamous cell carcinoma ( $p=0.003$ ), and an over expression of glucose-related protein (GRP94) was significantly associated with poor differentiation ( $p=0.048$ ). However, none of the HSP90 proteins showed a significant association with the survival status in patients with NSCLC. This study also indicates that HSP90 $\alpha$ might contribute more to the carcinogenesis of NSCLC than HSP90 $\beta$, and GRP94 and isoform selectivity should be considered when HSP90 inhibitors are studied or utilized in the treatment of NSCLC.
\end{abstract}

Key words: Heat shock protein $90 \alpha$, Heat shock protein90 $\beta$, Glucose related protein94, Non-small cell lung cancer This is an Open Access article distributed under the terms of the Creative Commons Attribution Non-Commercial License
(http://creativecommons.org/licenses/by-nc/4.0) which permits unrestricted non-commercial use, distribution, and reproduction in
any medium, provided the original work is properly cited.

Copyright (c) 2017 The Korean Society for Clinical Laboratory Science. All rights reserved.
Corresponding author: Mi Kyeong Kim Department of Clinical Laboratory Science, Gimhae College, 112 Saman-ro, Gimhae 50811, Korea

Tel: 82-55-320-1756

Fax: 82-55-336-6251

E-mail: mkkim@gimhae.ac.kr

Received: October 25, 2017

Revised $1^{\text {st: }}$ November 20, 2017

Revised $2^{\text {nd }}$ : November 22, 2017

Accepted: November 22, 2017

\section{INTRODUCTION}

Lung cancer shows the highest incidence and mortality rate in the world [1]. The incidence of lung cancer in Korea is fourth but first in the mortality rate. The number of deaths from lung cancer is increasing every year [2]. The 
five year survival rate of lung cancer is second only to pancreatic cancer. It is because lung cancer is not well treated and has fewer initial symptoms than other cancers. The symptoms of lung cancer are similar to those of respiratory diseases, including colds, so early diagnosis is very difficult.

Lung cancer is classified into non-small cell lung cancer and non-small cell lung cancer according to the size, shape, treatment method, prognosis, etc. Non-small cell lung cancer accounts for $85 \%$ of a total of lung cancers [3]. Non-small cell lung cancer is again divided into adenocarcinoma, squamous cell carcinoma, and large cell carcinoma.

Heat shock proteins (HSPs) were reported, which are induced as a self-defense mechanism of cells when we were exposed to various external stresses such as high fever, infection, free radicals, and heavy metals, then affecting the prognosis thereby in the process of tumor formation though [4-6]. Therefore, much research has been recently done in the area of new therapies or vaccine development using the regulation of HSPs expression [7]. HSP is classified into HSP27 family, HSP60, family HSP90 family, and HSP100 family depending on molecular weight $[4,5]$. The HSP90 family has two HSP90 isoforms in the cytoplasm, HSP90 $\alpha$ and HSP90 $\beta$. There exists glucose related protein 94 (GRP94) in the endoplasmic reticulum [8]. The HSP90 family has been reported to contribute to the maintenance of disease through the role of protecting unstable proteins in the cell but it is expressed at a higher level, compared to normal tissues [9-11]. It is known that proteins, such as MMP9, Her2 / ErbB2, v-Src, Hif-1 $\alpha$, Raf-1, AKT, EGFR, Met, etc. that play an important role in cancer cell growth and proliferation, are the client proteins of the HSP90 family [12-15]. It has been reported these proteins are involved in the signal transduction that converts normal cells into tumor cells [15-17]. Inhibitors of HSP90 are highlighted as a major target for cancer therapy $[18,19]$.

However, there has been no report of an association with the proliferation, metastasis, or prognosis of tumor. This study attempted to investigate the clinical usefulness as a bio-marker of cancer diagnosis by examining the relationship between the expression of the HSP90 family and the clinical pathology of non-small cell lung cancer.

\section{MATERIALS AND METHODS}

\section{Materials}

In this study, paraffin-embedded tissues of 72 patients were used as materials, who visited Samsung Changwon Hospital of Sungkyunkwan University from January in 2002 to December in 2009 and histopathologically diagnosed with non-small cell lung after Biopsy or radical surgery. For clinicopathologic features of each non-small cell lung cancer patient, such as gender, age, tumor size, metastasis, histologic type, grade, stage, Lymphovascular invasion, etc, the patients' medical records were examined and secured (Table 1). To identify lung cancer types, the type of lung cancer was microscopically determined according to the World Health Organization (WHO) classification after hematoxylin and eosin staining (H\&E staining) (Figure 1). The follow-up period to investigate the survival rate of patients was decided after a review of the medical records from January 2002 to July 2013. This study was approved through IRB deliberation (Review No. 2012-SCMC-044-00) of Samsung Changwon Hospital of Sungkyunkwan University.

\section{Method}

\section{1) Immunohistochemical staining}

To analyze the expression of the HSP90 family, immunohistochemical staining was performed. First, the tissue embedded in paraffin was cut into a thickness of $5 \mu \mathrm{m}$. After being attached to the slide, it was dried completely. Paraffin was removed being immersed in xylene three times for 3 minutes. Xylene was removed from 100\% alcohol. In order to remove the alcohol, the tissue was put in distilled water after 3 minutes of alcohol treatment of $95 \%, 80 \%, 70 \%$, and $50 \%$. The alcohol finally was removed. For the resurgence of antigenicity, $0.01 \mathrm{M}$ citrate buffer (pH 6.0) solution was added to the coplin jar and was heated in a microwave oven for about 10 minutes. After 
immersing the slide in citric acid buffer solution, it was heated in the microwave oven at $90^{\circ} \mathrm{C}$ to $100^{\circ} \mathrm{C}$ for 10 minutes. In order to prevent tissue from being exposed due to evaporation of the buffer solution, the solution was added as much as evaporated at intervals of 5 minutes and then the slide was heated again. The coplin jar was

Table 1. Clinicopathologic characteristics of 72 patients with non-small cell lung cancer

\begin{tabular}{|c|c|}
\hline \multirow{2}{*}{ Characteristics } & \multirow{2}{*}{$\begin{array}{l}\text { All Patients } \\
\text { Number (\%) }\end{array}$} \\
\hline & \\
\hline Total & $72(100)$ \\
\hline Median age (range) & $64(26 \sim 77)$ \\
\hline \multicolumn{2}{|l|}{ Sex } \\
\hline Male & $57(79)$ \\
\hline Female & $15(21)$ \\
\hline \multicolumn{2}{|l|}{ Smoking } \\
\hline Nonsmokers & $22(31)$ \\
\hline Smokers & $50(69)$ \\
\hline \multicolumn{2}{|l|}{ Histological type } \\
\hline SCC & $42(58)$ \\
\hline$A C$ & $30(42)$ \\
\hline \multicolumn{2}{|l|}{ Differentiation } \\
\hline Well & $26(36)$ \\
\hline Moderate & $34(47)$ \\
\hline Poor & $12(17)$ \\
\hline \multicolumn{2}{|l|}{ Tumor size $(\mathrm{cm})$} \\
\hline$\leq 3$ & $26(36)$ \\
\hline$>3$ & $46(64)$ \\
\hline \multicolumn{2}{|c|}{ Lympho node metastasis } \\
\hline Negative & $39(54)$ \\
\hline Positive & $33(46)$ \\
\hline \multicolumn{2}{|l|}{ Stage } \\
\hline । & $24(33)$ \\
\hline$\|$ & $13(18)$ \\
\hline III & $25(35)$ \\
\hline IV & $10(14)$ \\
\hline \multicolumn{2}{|c|}{ Lymphovascular invasion } \\
\hline Negative & $52(72)$ \\
\hline Positive & $20(28)$ \\
\hline
\end{tabular}

Abbreviations: SCC, squamous cell carcinoma; AC, adenocarcinoma. removed from the microwave oven and was cooled for 20 minutes at room temperature with the tissue soaked. Then, the slide was washed with phosphate-buffered saline (PBS). To prevent endogenous peroxidase activity, the slide was treated with $\mathrm{H} 2 \mathrm{O} 2$ for 10 minutes. After washing it twice with tris buffer, primary antibody (Zymed Co., San Francisco, USA) was treated for 10 minutes. Then, the primary antibody was reacted at room temperature for 30 minutes and washed twice with tris buffer. After the treatment of secondary antibody (Zymed Co., San Francisco, USA), it was reacted at room temperature for 10 minutes and washed twice with tris buffer. Reaction was carried out again with Avidin-biotin peroxidase complex $(\mathrm{ABC})$ at room temperature for 10 minutes and then washed three times with tris buffer. After reacted with diamino-benzidine (DAB) for 5 minutes and washed with PBS for 5 minutes. After stained for 1 minute with the control stain Mayer's Hematoxylin, it was rinsed with water for 10 minutes. It was dehydrated with alcohol and xylene and sealed with canada balsam, examined with a microscope. As a negative control group, tissues from benign lung disease patients were used.

\section{Statistical analysis}

For immunohistochemical staining results, chi-square test was used to find out the degree of positive expression and clinicopathologic characteristics. For survival analysis, Kaplan-Meier model was used. The survival rates according to the degree of expression were compared using the Log Rank method.

Statistical analysis was performed using SPSS version 18.0 (SPSS Inc., Chicago, USA). The significance level was
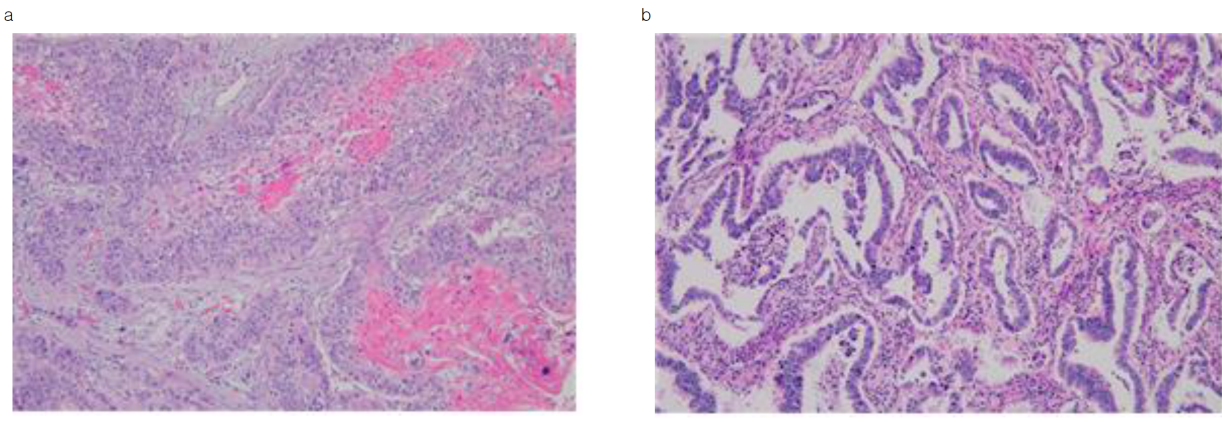

Figure 1. Comparison of squamous cell carcinoma and adenocarcinoma by H\&E staining. (a) Squamous cell carcinoma resembles stratified squamous epithelium of the upper airway and shows obvious keratinization. (b) Adenocarcinoma consists of malignant glands invading a fibrous stroma. 
considered at $p<0.05$.

\section{RESULTS}

\section{Correlation between clinicopathologic characteristics and expression of HSP90 family in non-small cell lung cancer patients}

In the interpretation of immunohistochemical staining conducted to investigate the correlation between the clinicopathologic characteristics and the expression of the HSP90 family in non-small cell lung cancer patients, if DAB coloration (brown) is less than $5 \%$ by converting the area subjected to the dyeing into a percentage, it was decided to read,$- 25 \%$. When less than 25 to $50 \%$, it was decided to read,$++50 \%$. When more than $50 \%$, it was determined to read +++. The results of immunohistochemical staining was divided in a group of lower expression (less than -, $+/ 25 \%)$ and a group of higher expression (more than ++ , +++ / 25\%) (Figure 2).

\section{1) Correlation with expression of HSP90 $\alpha$}

Analysis was conducted to find out the correlation between clinicopathologic characteristics and the expression of HSP90 $\alpha$ in non-small cell lung cancer patients by immunohistochemical staining. As a result of that, out of a total of 72 cases, 27 ones (37.5\%) showed lower expression, 45 ones (62.5\%) were highly expressed. There was no difference in the expression of HSP90 $\alpha$ according to age and sex. Depending on the presence or absence of smoking, out of 22 cases of non - smoking, high expression was observed in 10 cases (45.5\%). 35 cases (70.0\%) out of 50 smoking ones showed high expression with significance ( $p=0.048$ ). In histologic type, squamous cell carcinoma, 29 cases (69.0\%) out of 42 ones showed higher expression. In adenocarcinoma, 16 cases (53.3\%) out of 30 ones showed higher expression. There was no significant. In the degree of differentiation, 16 cases (61.5\%) out of 26 ones with higher differentiation rate showed higher expression. 20 cases (58.8\%) out of 34 ones with moderate differentiation were higher in expression. 9 cases $(75.0 \%)$ out of 12 ones

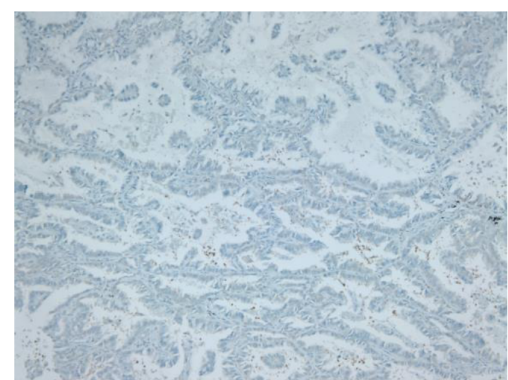

d

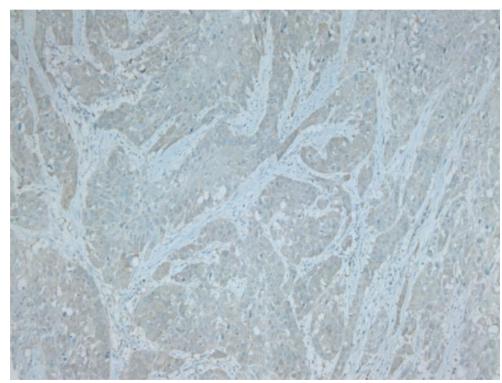

$\mathrm{b}$
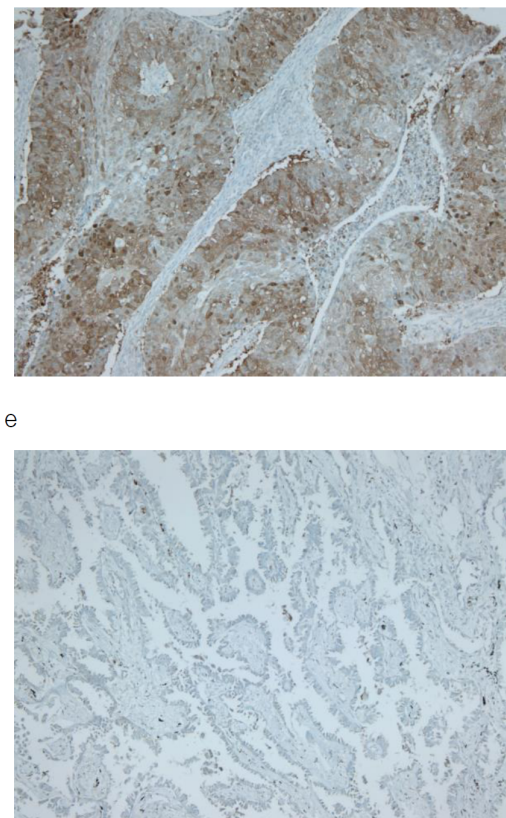
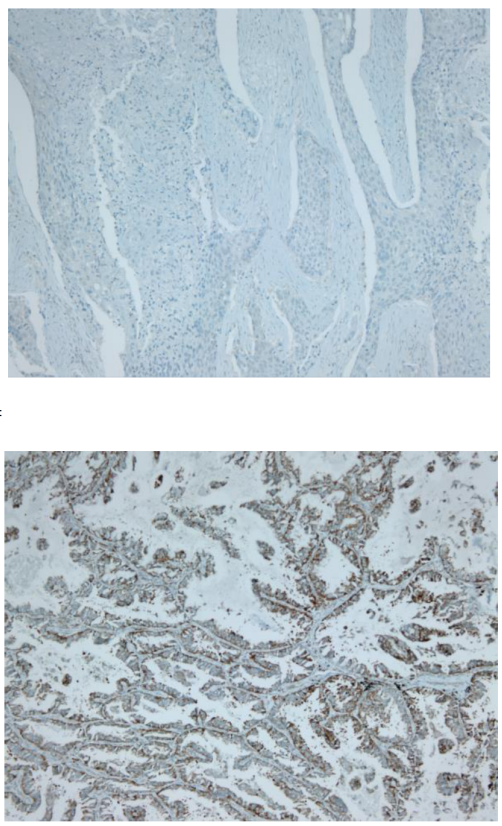

Figure 2. Immunohistochemical staining for HSP90 $\alpha$, HSP90ß and GRP94 in non-small cell lung cancer. Immunohistochemical detection was performed using DAB (brown) and nuclei were stained with hematoxylin (blue). Brown color indicates positive reaction. (a) Non-small cell lung cancer represent low staining for HSP90 $\alpha$. (b) Non-small cell lung cancer show high cytoplasmic expression of HSP90 . (c) Non-small cell lung cancer represent low staining for HSP90ß. (d) Non-small cell lung cancer show high cytoplasmic expression of HSP90ß. (e) Non-small cell lung cancer represent low staining for GRP94. (f) Non-small cell lung cancer show high cytoplasmic expression of GRP94. 
with low differentiation showed higher expression, which was not significant, however. In tumor size, 14 cases (53.8\%) out of 26 ones with $\leq 3 \mathrm{~cm}$ showed higher expression. 31 cases $(67.4 \%)$ out of 46 ones with $>3$ were also higher in expression. In lymph node metastasis, 23 cases $(59.0 \%)$ out of 39 ones without metastasis showed higher expression, the same as 22 cases (66.7\%) out of 33 ones with metastasis. However, there was no significant. Depending on the stage, 15 cases (62.5\%) out of 24 ones in stage I, 7 cases (53.8\%) out of 13 ones in stage II, 17 cases (68.0\%) out of 25 ones in stage III, and 6 cases (60.0\%) out of 10 cases in stage IV showed higher expression, which were statistically insignificant, however. In lymphovascular invasion, 37 cases (71.2\%) out of 52 non-lymphovascular invasion ones, and 8 cases out of 20 lymphovascular invasion ones (40.0\%) respectively showed higher expression ( $p=0.014$ ), which was significant (Table 2).

\section{2) Correlation with expression of HSP90 $\beta$}

Analysis was conducted to find out the correlation between clinicopathologic characteristics and the expression of HSP90 $\alpha$ in non-small cell lung cancer patients by performing immunohistochemical staining. As a result of that, out of a total of 72 cases, 43 cases (59.7\%) showed low expression, 29 cases (40.3\%) were highly expressed. According to age, 22 cases (59.1\%) out of 37 ones with $<65$ and 12 cases out of 35 ones with $\geq 65$ showed higher expression. Depending on sex, 25 cases (43.9\%) out of 57 ones in males and 4 cases (26.7\%) out of 15 cases were higher in expression. Both age and sex were not significant. Depending on smoking or not, 6 cases (27.3\%) out of non-smoking ones and 23 cases out of 53 smoking cases indicated higher expression with no significance. In histological type, 23 cases $(54.8 \%)$ out of 42 cases of squamous cell carcinoma showed higher expression. In adenocarcinoma, expression was higher in 6 cases $(20.0 \%)$ out of 30 cases. There was significant difference $(p=0.003)$. In differentiation degree, 7 cases (26.9\%) of 26 ones with high differentiation degree, 17 cases $(50.0 \%)$ out of 34 ones with moderate differentiation, and 5 cases ( $41,7 \%$ out of 12 ones in the low differentiation group showed higher expression without significance. In tumor size, 10 cases (38.5\%) out of 26 ones with $\leq 3 \mathrm{~cm}$ and 19 cases (41.3\%) out of 46 ones with $>3$ showed higher expression. In lymph node metastasis, 16 cases (41.0\%) out of 39 cases without metastasis showed higher expression without significance. Depending on the stage, 12 cases (50.0\%) out of 24 ones in stage I, 3 cases (23.2\%) out of 13 ones in stage II, 11 cases (44.0\%) out of 25 ones in stage III, and 3 cases (30.0\%) out of 10 ones in stage IV showed higher expression, which was statistically insignificant. In lymphovascular invasion, 24 cases (46.2\%) out of 52 non-lymphovascular invasion ones, and 5 cases (25.5\%) out of 20 lymphovascular

Table 2. Correlation between HSP90 $\alpha$ expression and clinicopathologic characteristics in 72 patients with non-small cell lung cancer

\begin{tabular}{|c|c|c|c|c|}
\hline \multirow{2}{*}{ Characteristics } & \multirow{2}{*}{$\begin{array}{c}\text { Number } \\
(\%)\end{array}$} & \multicolumn{3}{|c|}{ HSP90 $\alpha$} \\
\hline & & L (\%) & $\mathrm{H}(\%)$ & $p$ value \\
\hline Total & $72(100)$ & $27(37.5)$ & $45(62.5)$ & \\
\hline \multicolumn{5}{|l|}{ Age (years) } \\
\hline$<65$ & $37(51)$ & $15(40.5)$ & $22(59.5)$ & \multirow[t]{2}{*}{0.584} \\
\hline$\geq 65$ & 35 (49) & $12(34.3)$ & $23(65.7)$ & \\
\hline \multicolumn{5}{|c|}{ 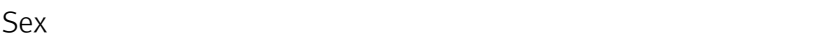 } \\
\hline Male & $57(79)$ & $20(35.1)$ & $37(64.9)$ & \multirow[t]{2}{*}{0.410} \\
\hline Female & $15(21)$ & $7(46.7)$ & $8(53.3)$ & \\
\hline \multicolumn{5}{|l|}{ Smoking } \\
\hline Nonsmokers & $22(31)$ & $12(54.5)$ & $10(45.5)$ & \multirow[t]{2}{*}{0.048} \\
\hline Smokers & $50(69)$ & $15(30.0)$ & $35(70.0)$ & \\
\hline \multicolumn{5}{|l|}{ Histological type } \\
\hline SCC & $42(58)$ & $13(31.0)$ & $29(69.0)$ & \multirow[t]{2}{*}{0.175} \\
\hline$A C$ & $30(42)$ & $14(46.7)$ & $16(53.3)$ & \\
\hline \multicolumn{5}{|l|}{ Differentiation } \\
\hline Well & $26(36)$ & $10(38.5)$ & $16(61.5)$ & \multirow[t]{3}{*}{0.605} \\
\hline Moderate & $34(47)$ & $14(41.2)$ & $20(58.8)$ & \\
\hline Poor & $12(17)$ & $3(25.0)$ & $9(75.0)$ & \\
\hline \multicolumn{5}{|l|}{ Tumor size $(\mathrm{cm})$} \\
\hline$\leq 3$ & $26(36)$ & $12(46.2)$ & $14(53.8)$ & \multirow[t]{2}{*}{0.254} \\
\hline$>3$ & $46(64)$ & $15(32.6)$ & $31(67.4)$ & \\
\hline \multicolumn{5}{|c|}{ Lympho node metastasis } \\
\hline Negative & $39(54)$ & $16(41.0)$ & $23(59.0)$ & \multirow[t]{2}{*}{0.502} \\
\hline Positive & $33(46)$ & $11(33.3)$ & $22(66.7)$ & \\
\hline \multicolumn{5}{|l|}{ Stage } \\
\hline 1 & $24(33)$ & $9(37.5)$ & $15(62.5)$ & \multirow[t]{4}{*}{0.858} \\
\hline$\|$ & $13(18)$ & $6(46.2)$ & $7(53.8)$ & \\
\hline III & $25(35)$ & $8(32.0)$ & $17(68.0)$ & \\
\hline IV & $10(14)$ & $4(40.0)$ & $6(60.0)$ & \\
\hline \multicolumn{5}{|c|}{ Lymphovascular invasion } \\
\hline Negative & $52(72)$ & $15(28.8)$ & $37(71.2)$ & \multirow[t]{2}{*}{0.014} \\
\hline Positive & $20(28)$ & $12(60.0)$ & $8(40.0)$ & \\
\hline
\end{tabular}

Abbreviations: L, low expression (less than 25\%); $\mathrm{H}$, high expression (over 25\%); SCC, squamous cell carcinoma; AC, adenocarcinoma. 
invasionones showed higher expression ( $p=0.014)$, which was not significant (Table 3).

\section{3) Correlation with expression of GRP94}

In GRP94 expression analyzed by immunohistochemical staining, out of a total of 72 cases, 31 cases (43.1\%) showed lower expression and 41 cases (56.9\%) were highly expressed. Depending on age, 21 cases $(56.8 \%)$ out of 37 ones at 65 and 20 cases $(57.1 \%$ ) out of 35 ones at $\geq 65$ showed higher expression. However, both age and sex were not significant. Depending on smoking or not, 11 cases (50.0\%) out of 22 non-smoking ones and 30 cases

Table 3. Correlation between HSP90 $\beta$ expression and clinicopathologic characteristics in 72 patients with non-small cell lung cancer

\begin{tabular}{|c|c|c|c|c|}
\hline \multirow{2}{*}{ Characteristics } & \multirow{2}{*}{$\begin{array}{c}\text { Number } \\
(\%)\end{array}$} & \multicolumn{3}{|c|}{ HSP90 $\beta$} \\
\hline & & L (\%) & $\mathrm{H}(\%)$ & $p$ value \\
\hline Total & $72(100)$ & $43(59.7)$ & $29(40.3)$ & \\
\hline \multicolumn{5}{|l|}{ Age (years) } \\
\hline$<65$ & $37(51)$ & $20(54.1)$ & $22(59.1)$ & \multirow[t]{2}{*}{0.313} \\
\hline$\geq 65$ & 35 (49) & $23(65.1)$ & 12 (34.3) & \\
\hline \multicolumn{5}{|c|}{ (2) } \\
\hline Male & 57 (79) & $32(56.1)$ & $25(43.9)$ & \multirow[t]{2}{*}{0.227} \\
\hline Female & $15(21)$ & $11(73.3)$ & $4(26.7)$ & \\
\hline \multicolumn{5}{|l|}{ Smoking } \\
\hline Nonsmokers & $22(31)$ & $16(72.7)$ & $6(27.3)$ & \multirow[t]{2}{*}{0.136} \\
\hline Smokers & $50(69)$ & $27(54.0)$ & $23(46.0)$ & \\
\hline \multicolumn{5}{|l|}{ Histological type } \\
\hline SCC & $42(58)$ & $19(45.2)$ & $23(54.8)$ & \multirow[t]{2}{*}{0.003} \\
\hline$A C$ & $30(42)$ & $24(80.0)$ & $6(20.0)$ & \\
\hline \multicolumn{5}{|l|}{ Differentiation } \\
\hline Well & $26(36)$ & $19(73.1)$ & 7 (26.9) & \multirow[t]{3}{*}{0.195} \\
\hline Moderate & $34(47)$ & $17(50.0)$ & $17(50.0)$ & \\
\hline Poor & 12 (17) & 7 (58.3) & $5(41.7)$ & \\
\hline \multicolumn{5}{|l|}{ Tumor size $(\mathrm{cm})$} \\
\hline$\leq 3$ & $26(36)$ & $16(61.5)$ & $10(38.5)$ & \multirow[t]{2}{*}{0.813} \\
\hline$>3$ & $46(64)$ & $27(58.7)$ & $19(41.3)$ & \\
\hline \multicolumn{5}{|c|}{ Lympho node metastasis } \\
\hline Negative & $39(54)$ & $23(59.0)$ & $16(41.0)$ & \multirow[t]{2}{*}{0.888} \\
\hline Positive & $33(46)$ & $20(60.6)$ & $13(39.4)$ & \\
\hline \multicolumn{5}{|l|}{ Stage } \\
\hline 1 & $24(33)$ & $12(50.0)$ & $12(50.0)$ & \multirow[t]{4}{*}{0.373} \\
\hline$\|$ & $13(18)$ & $10(76.9)$ & $3(23.1)$ & \\
\hline III & $25(35)$ & $14(56.0)$ & $11(44.0)$ & \\
\hline IV & $10(14)$ & $7(70.0)$ & $3(30.0)$ & \\
\hline \multicolumn{5}{|c|}{ Lymphovascular invasion } \\
\hline Negative & $52(72)$ & $28(53.8)$ & $24(46.2)$ & \multirow[t]{2}{*}{0.101} \\
\hline Positive & $20(28)$ & $15(75.0)$ & $5(25.0)$ & \\
\hline
\end{tabular}

Abbreviations: L, low expression (less than 25\%); $\mathrm{H}$, high expression (over 25\%); SCC, squamous cell carcinoma; AC, adenocarcinoma.
(60.0\%) out of 50 smoking ones showed higher expression without significance. In histological type, 23 cases (54.8\%) out of 42 squamous cell carcinoma cases showed higher expression. In adenocarcinoma, expression was higher in 18 cases (60.0\%) of 30 ones but there was no significant. In differentiation degree, 10 cases (38.5\%) out of 26 ones with higher differentiation degree, 22 cases (64.7\%) out of 34 ones with moderate differentiation, and 9 cases $(75.0 \%)$ out of 12 ones with lower differentiation degree showed higher expression. There was statistically significant ( $p=0.048$ ). In tumor size, 16 cases (61.5\%) out of 26 ones with $\leq 3 \mathrm{~cm}$ and 25 cases (54.3\%) out of 46 ones with $>3$

Table 4. Correlation between GRP94 expression and clinicopathologic characteristics in 72 patients with non-small cell lung cancer

\begin{tabular}{|c|c|c|c|c|}
\hline \multirow{2}{*}{ Characteristics } & \multirow{2}{*}{$\begin{array}{c}\text { Number } \\
(\%)\end{array}$} & \multicolumn{3}{|c|}{ GRP94 } \\
\hline & & L (\%) & $\mathrm{H}(\%)$ & $p$ value \\
\hline Total & $72(100)$ & $31(43.1)$ & $41(56.9)$ & \\
\hline \multicolumn{5}{|l|}{ Age (years) } \\
\hline$<65$ & $37(51)$ & $16(43.2)$ & $21(56.8)$ & \multirow{2}{*}{0.974} \\
\hline$\geq 65$ & $35(49)$ & $15(42.9)$ & $20(57.1)$ & \\
\hline \multicolumn{5}{|c|}{ (е) } \\
\hline Male & $57(79)$ & $24(42.1)$ & $33(57.9)$ & \multirow{2}{*}{0.751} \\
\hline Female & $15(21)$ & $7(46.7)$ & $8(53.3)$ & \\
\hline \multicolumn{5}{|l|}{ Smoking } \\
\hline Nonsmokers & $22(31)$ & $11(50.0)$ & $11(50.0)$ & \multirow{2}{*}{0.430} \\
\hline Smokers & $50(69)$ & $20(40.0)$ & $30(60.0)$ & \\
\hline \multicolumn{5}{|l|}{ Histological type } \\
\hline SCC & $42(58)$ & $19(45.2)$ & $23(54.8)$ & \multirow{2}{*}{0.658} \\
\hline$A C$ & $30(42)$ & $12(40.0)$ & $18(60.0)$ & \\
\hline \multicolumn{5}{|l|}{ Differentiation } \\
\hline Well & $26(36)$ & $16(61.5)$ & $10(38.5)$ & \multirow[t]{3}{*}{0.048} \\
\hline Moderate & $34(47)$ & $12(35.3)$ & $22(64.7)$ & \\
\hline Poor & $12(17)$ & $3(25.0)$ & $9(75.0)$ & \\
\hline \multicolumn{5}{|l|}{ Tumor size $(\mathrm{cm})$} \\
\hline$\leq 3$ & $26(36)$ & $10(38.5)$ & $16(61.5)$ & \multirow{2}{*}{0.554} \\
\hline$>3$ & $46(64)$ & $21(45.7)$ & $25(54.3)$ & \\
\hline \multicolumn{5}{|c|}{ Lympho node metastasis } \\
\hline Negative & $39(54)$ & $19(48.7)$ & $20(51.3)$ & \multirow{2}{*}{0.291} \\
\hline Positive & $33(46)$ & $12(36.4)$ & $21(63.6)$ & \\
\hline \multicolumn{5}{|l|}{ Stage } \\
\hline 1 & $24(33)$ & $10(41.7)$ & 14(58.3) & \multirow[t]{4}{*}{0.573} \\
\hline$\|$ & $13(18)$ & $4(30.8)$ & $9(69.2)$ & \\
\hline III & $25(35)$ & $11(44.0)$ & $14(56.0)$ & \\
\hline IV & $10(14)$ & $6(60.0)$ & $4(40.0)$ & \\
\hline \multicolumn{5}{|c|}{ Lymphovascular invasion } \\
\hline Negative & $52(72)$ & $23(44.2)$ & $29(55.8)$ & \multirow{2}{*}{0.745} \\
\hline Positive & $20(28)$ & $8(40.0)$ & $12(60.0)$ & \\
\hline
\end{tabular}

Abbreviations: L, low expression (less than 25\%); $\mathrm{H}$, high expression (over 25\%); SCC, squamous cell carcinoma; AC, adenocarcinoma. 
cm showed higher expression. In lymph node metastasis, 20 cases $(51.3 \%)$ out of 39 ones without metastasis and 21 cases $(63.6 \%)$ out of 33 ones with metastasis showed higher expression with no significance. Depending on stage, 14 cases $(58.3 \%)$ out of 24 ones in stage I, 9 cases (69.2\%) out of 13 ones in stage II, 14 cases (56.0\%) out of 25 ones in stage III, and 4 cases (40\%) out of 10 ones in stage IV were higher in the expression without significance. In lymphovascular invasion, 29 cases (55.8\%) out of 52 non-lymphovascular invasion ones and 12 cases (60.0\%) out of 20 lymphovascular invasion ones showed higher expression without significance (Table 4).

\section{Correlation between patient survival and expression of HSP90 family}

As a result of the follow-up of non-small cell lung cancer patients from January 2002 to July 2009, the mean follow-up period turned out 31 months. Of a total of 72 patients, $38(52.8 \%)$ died due to disease progression. Survival rates were analyzed by converting the area subjected to dying into a percentage. In this case, when the stained area was less than 25\%, the expression was defined lower; when more than $25 \%$, the stained area was divided into higher. There was no statistically significant difference between HSP90 $\alpha$ expression and the survival rate in non-small cell lung cancer patients ( $p=0.625$ ). In addition, no statistically significant difference was found between the difference of HSP90 $\beta$ expression and the survival rate ( $p=0.388$ ). For GRP94 as well, there was no statistically significant difference between the difference of GRP94 expression and the survival rate $(p=0.589)$ (Figure 3$)$.

\section{DISCUSSION}

The HSP90 family is composed of proteins such as HSP90 $\alpha$, HSP90 $\beta$, and glucose-regulated protein 94 (GRP94). It was found that MMP9, Her2 / ErbB2, v-Src, Hif- $1 \alpha$, Raf-1, AKT, EGFR, Met, etc., associated with the production of tumor cells, are the client protein of HSP90 [13-15]. Therefore, the inhabitation of HSP90 can suppress highly - expressed client proteins in tumor cells. For this reason, a drug inhibiting HSP90 is functionally recognized now as an anticancer drug for the treatment of non-small cell lung cancer, which is under clinical trials [8]. However,
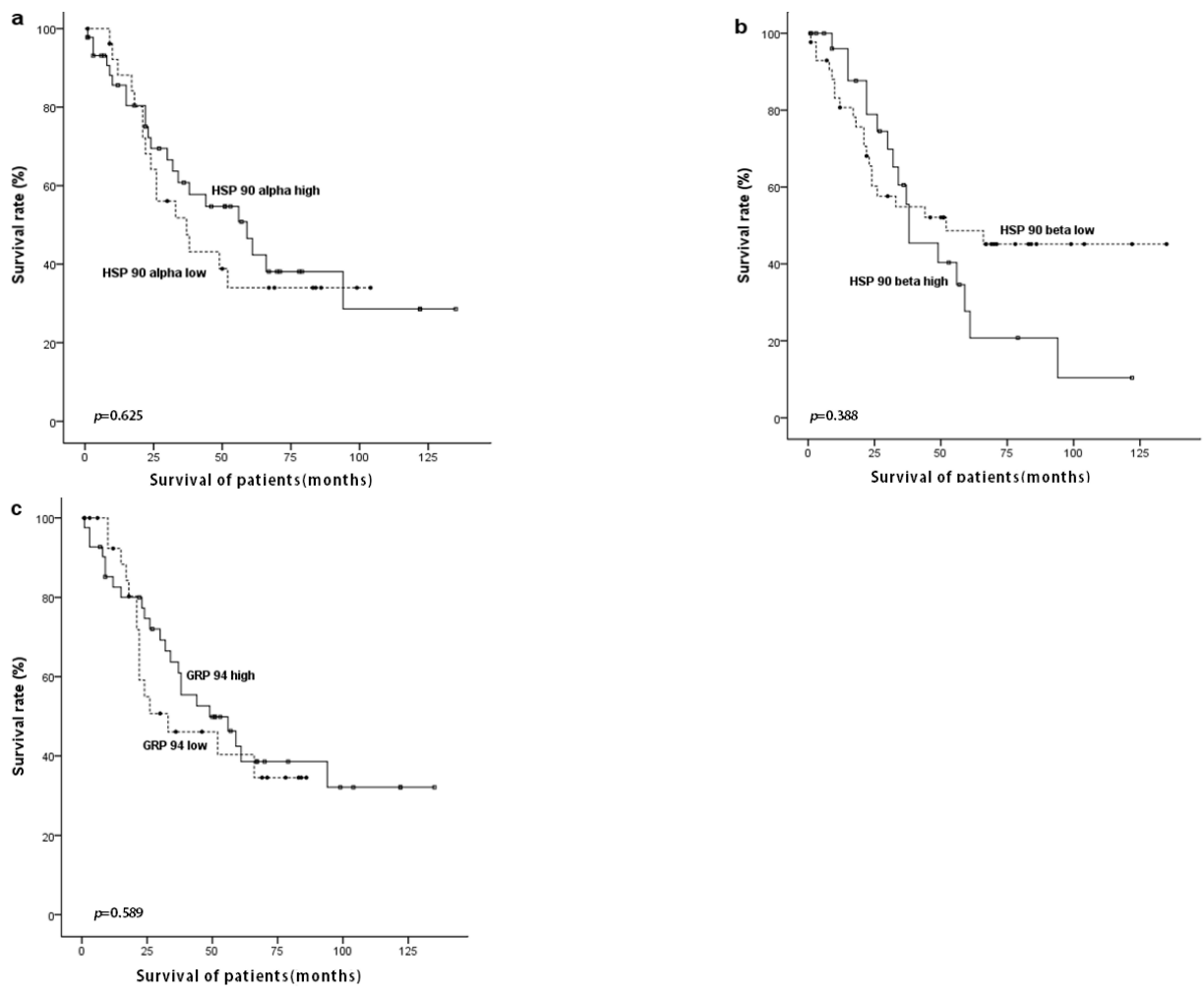

Figure 3. Survival analysis of 72 non-small cell lung cancer using the Kaplan-Meier method. The patients were grouped as high (over 25\%) and low (less than 25\%) expression groups for the HSP90 $\alpha$ (a), HSP90 $\beta$ (b) and GRP94 (c). 
there has been no report on the association with the proliferation, metastasis, and prognosis of non-small cell lung cancer. Thus, this study tried to examine clinical usefulness as a biomarker of cancer diagnosis by performing immunohistochemical staining and analyzing the relationship between the expression of the HSP90 family and clinicopathologic characteristics of non-small cell lung cancer patients.

For HSP90, it has been reported that expression increases in breast cancer, pancreatic cancer, esophageal squamous cell carcinoma, and acute leukemia [20-22]. Given the increased expression of HSP90 $\alpha$, HSP90 is thought to show an increasing tendency in various cancers. In the correlation with clinicopathologic characteristics, higher expression was observed in tissues without lymph node metastasis $(p=0.014)$. Jiang et al. also showed a higher tendency of expression in tissues without lymph node metastasis in pancreatic cancer [20]. However, Zuo et al. reported over-expression in tissues with lymph node metastasis in stomach cancer [23]. Therefore, expression of HSP90 $\alpha$ and lymph node metastasis may differ depending on the tumor.

HSP90 $\beta$ has been reported to be over-expressed in small cell lung cancer, pancreatic endocrine tumor, colon cancer, etc. [24-26]. However, this study showed $40.3 \%$ of lower expression. This may be due to the differences in the criteria for classification of expression patterns. In histopathologic classification, higher expression was found in squamous cell carcinoma ( $p=0.003)$. Biaoxue et al. also reported similar results [27]. This suggests that the difference in the expression of HSP90 $\beta$ seems to be dependent on the type of tumor. In a study by Biaoxue et al, the expression of HSP90 $\beta$ in all lung cancers was higher in low differentiation, lymphovascular invasion, and higher stages. They reported that the results are significant [27] and Lee et al. reported that there was no significant difference in tumor size, lymph node metastasis, and stages in small cell lung cancer [26]. In this study, although there is a difference in the histological type of lung cancer, the results are similar to those of Lee et al. However, it is considered that many studies should be performed on histologic types of lung cancer.

It has been reported that GRP94 is over-expressed in endometrial cancer, small cell lung cancer, and multiple myeloma $[26,28,29]$. In a study by Wang et al, GRP94 showed over-expression in all lung cancer types, at low differentiation, and in higher stages as well. They thus reported statistical significance [30]. In this study, GRP94 exhibited higher expression with lower degree of differentiation, so there was statistically significant $(p=0.048)$; however. it was not statistically significant in relation to stages. These results suggest that GRP94 is involved in tumor progression and is available as a prognostic factor.

This study did not show a significant correlation between the HSP90 family and clinical pathologic survival. However, there was a difference in expression among proteins in the HSP90 family. HSP90 $\alpha$ showed higher expression than HSP90 $\beta$ or GRP94. The result suggests that HSP90 $\alpha$ is more likely to contribute to tumor development than HSP90 $\beta$ or GRP94 in non-small cell lung cancer.

In conclusion, $\mathrm{HSP} 90 \alpha$ out of the proteins HSP90 showed a higher expression in terms of the correlation among the expression of the HSP90 family, clinicopathologic characteristics, and the survival rate. The results suggest that for the treatment of non-small cell lung cancer, it is thought that the family of HSP90 should be considered in the study and for the selection of HSP inhibitors and that GRP94 may be an important biological marker for the prognosis of the tumor.

\section{요 약}

열충격 단백질(heat shock proteins, HSPs)은 다양한 종양 에서 과발현 되고, 종양이 형성되는 과정이나 그 예후에 영향을 주며, 분자량에 따라 HSP27, HSP60, HSP90, HSP100 등으로 구분한다. Heat shock protein90은 세포 내 불안정한 단백질 을 보호하는 역할을 통해 질병의 유지에 기여하는데, 정상 조직 에 비해 종양 세포에서 높은 수준으로 발현된다고 보고되었다. 이에 본 연구에서는 우리나라 사망원인 1 위인 폐암 중 비소세포 폐암에서 Heat shock protein90 family 발현과 비소세포 폐암 환자의 임상적 특징과의 상관관계를 분석하여 종양의 생물학적 
표지자로서의 가능성을 조사하였다. HSP90 family의 발현과 임상병리학적 특성 및 생존율과의 상관관계를 분석한 결과 $\mathrm{HSP90 \alpha 는} \mathrm{림프혈관강} \mathrm{침윤이} \mathrm{되지} \mathrm{않은} \mathrm{환자에서} \mathrm{높은} \mathrm{발현을}$ 보였고 $(p=0.014), \mathrm{HSP} 90 \beta$ 은 조직학적 형태에서 편평상피세 포 암종에서 높은 발현을 보였으며( $p=0.003), \mathrm{GRP} 94$ 은 분화 도가 낮을수록 높은 발현을 나타내었다( $p=0.048)$. 생존율은 $\mathrm{HSP90} \alpha, \mathrm{HSP} 90 \beta, \mathrm{GRP} 94$ 모두 발현 차이에 대한 유의성이 없 었다. 본 연구를 통해 miRNA-126, miRNA-155, miRNA-200c 의 발현은 비소세포 폐암의 진단을 위한 생물학적 표지자 및 예 후 인자로서 사용될 수 있을 것으로 사료된다. 그리고 비소세포 폐암의 치료용으로 HSP90 family가 고려되어야 할 것이며, GRP94가 종양의 예후예측을 위한 중요한 인자라 사료된다.

\section{Acknowledgements: None}

Funding: None

Conflict of interest: None

\section{REFERENCES}

1. International Agency for Research on Cancer. GLOBOCAN 2012: Estimated cancer incidence, mortality and prevalence worldwide in 2012 [Internet]. Lyon: International Agency for Research on Cancer; 2012 [cited 2017 August 01] Available from http://globocan.iarc.fr/Pages/fact_sheets_cancer/.

2. National Cancer Information Center. Cancer Statistics in Korea. 2014 [Internet]. Goyang: National Cancer Information Center; 2014 [cited 2017 August 01] Korea Available from: http://www.cancer.go.kr/mbs/cancer/subview.jsp

3. Brandao GD, Brega EF, Spatz A. The role of molecular pathology in non-small-cell lung carcinoma-now and in the future. Curr Oncol. 2012;19(1):24-32.

4. Kingstone RE, Baldwin, AS, Sharp PA. Regulation of heat shock protein 70 gene expression by c-myc. Nature. 1984;312(5991): 280-282.

5. Konno A, Sato N, Yagihashi A, Torigoe T, Cho JM, Torimoto K, et al. Heat or stress inducible transformation associated cell surface antigen on the H-ras oncogene transfected rat fibroblasts. Cancer Res. 1989;49(23):6578-6582.

6. Shrivastava PK, Maki RG. Stress induced proteins in immune response to cancer. Curr Top Microbiol Immunol. 1991; 167:109-123.

7. Bukau B, Horwich AL. The Hsp70 and Hsp60 chaperone machines. Cell. 1998;92(3):351-366.

8. Garcia-Carbonero R, Carnero A, Paz-Ares L. Inhibition of HSP90 molecular chaperones: moving into the clinic. Lancet Oncol. 2013;14(9):358-369.

9. McClellan AJ, Xia Y, Deutschbauer AM, Davis RW, Gerstein M, Frydman J. Diverse cellular functions of the Hsp90 molecular chaperone uncovered using systems approaches. Cell. 2007; 131(1):121-135.
10. Dobo C, Stavale JN, Lima Fde O, Ribeiro DA, Arias V, Gomes TS, et al. HSP27 is Commonly Expressed in Cervical Intraepithelial Lesions of Brazilian Women. Asian Pac J Cancer Prev. 2013; 14(9):5007-5010.

11. Wu GQ, Liu NN, Xue XL, Cai LT, Zhang C, Qu QR, et al. Multiplex Real-time PCR for RRM1, XRCC1, TUBB3 and TS mRNA for prediction of response of non-small cell lung cancer to chemoradiotherapy. Asian Pac J Cancer Prev. 2014;15(10): 4153-4158.

12. Hanahan D, Weinberg RA. The hallmarks of cancer. Cell. 2000;100(1):57-70.

13. Mahalingam D, Swords R, Carew JS, Nawrocki ST, Bhalla K, Giles FJ. Targeting HSP90 for cancer therapy. Br J Cancer. 2009;100(10):1523-1529.

14. Sharp S. Workman P. Inhibitors of the HSP90 molecular chaperone: current status. Adv Cancer Res. 2006;95:323-348.

15. Hanahan D, Weinberg RA. Hallmarks of cancer: the next generation. Cell. 2011;144(5):646-674.

16. Beck R, Dejeans N, Glorieux C, Pedrosa RC, Vásquez D, Valderrama JA, Calderon PB, Verrax J. Molecular chaperone Hsp90 as a target for oxidant-based anticancer therapies. Curr Med Chem. 2011;18(18):2816-2825.

17. Moser C, Lang SA, Stoeltzing O. Heat-shock protein 90(Hsp90) as a molecular target for therapy of gastrointestinal cancer. Anticancer Res. 2009;29(6):2031-2042.

18. Whitesell L, Lindquist SL. Hsp90 and chaperoning of cancer. Nat Rev Cancer. 2005;5(10):761-772.

19. Jia JM, Liu F, Xu XL, Guo XK, Jiang F, Cherfaoui B, et al. Synthesis and evaluation of a novel class Hsp90 inhibitors containing 1-phenylpiperazine scaffold. Bioorg Med Chem Lett. 2014;24(6):1557-1561.

20. Jiang H, Duan B, He C, Geng S, Shen X, Zhu H, et al. Cytoplasmic HSP90 $\alpha$ expression is associated with perineural invasion in pancreatic cancer. Int J Clin Exp Pathol. 2014; 7(6):3305-3311.

21. Tian WL, He F, Fu X, Lin JT, Tang P, Huang YM, et al. High expression of heat shock protein 90 alpha and its significance in human acute leukemia cells. Gene. 2014;542(2):122-128.

22. Romaniuk A, L y ndin M. Immune microenvironment as a factor of breast cancer progression. Diagnostic Pathology. 2015; 10:79.

23. Zuo DS, Dai J, Bo AH, Fan J, Xiao XX. Significance of expression of heat shock protein90 $\alpha$ in human gastric cancer. World J Gastroenterol. 2003;9(11):2616-2618.

24. Jahns F, Wilhelm A, Greulich KO, Mothes H, Radeva M, Wölfert A, et al. Impact of butyrate on PKM2 and HSP90 $\beta$ expression in human colon tissues of different transformation stages: a comparison of gene and protein data. Genes Nutr. 2012;7(2): 235-246.

25. Mayer P, Harjung A, Breinig M, Fischer L, Ehemann V, Malz M, et al. Expression and therapeutic relevance of heat-shock protein 90 in pancreatic endocrine tumors. Endocr Relat Cancer. 2012;19(3):217-232.

26. Lee JH, Kang KW, Kim JE, Hwang SW, Park JH, Kim SH, et al. Differential expression of heat shock protein 90 isoforms in small cell lung cancer. Int J Clin Exp Pathol. 2015;8(8): 9487-9493. 
27. Biaoxue R, Xiling J, Shuanying Y, Wei Z, Xiguang C, Jinsui W, et al. Upregulation of Hsp90-beta and annexin A1 correlates with poor survival and lymphatic metastasis in lung cancer patients. J Exp Clin Cancer Res. 2012;31(1):70.

28. Chhabra S, Jain S, Wallace C, Hong F. Liu B. High expression of endoplasmic reticulum chaperone grp94 is a novel molecular hallmark of malignant plasma cells in multiple myeloma. J Hematol Oncol. 2015;8:77.
29. Shen J, Yao L, Lin YG, DeMayo FJ, Lydon JP, Dubeau L, et al. Glucose-regulated protein 94 deficiency induces squamous cell metaplasia and suppresses PTEN-null driven endometrial epithelial tumor development. Oncotarget. 2016;7(12):14885-14897.

30. Wang Q, He Z, Zhang J, Wang Y, Wang T, Tong S, et al. Overexpression of endoplasmic reticulum molecular chaperone GRP94 and GRP78 in human lung cancer tissues and its significance. Cancer Detect Prev. 2005;29(6):544-551. 